\title{
CAPABILITIES TO COMBAT HELICOPTERS BY WARSHIPS OF POLISH NAVY IN THE LIGHT OF THE DEVELOPMENT OF ACTIVE SYSTEMS TO COUNTERACT SETS MANPADS
}

\author{
Paweł Dobrzyński*, Stanisław Lipski**, \\ Bogdan Machowski*, Rafał Miętkiewicz***, \\ Sławomir Tamberg****
}

* Military University of Technology, Faculty of Mechatronics and Aviation, gen. W. Urbanowicza 2 Str., 00-908 Warsaw, Poland; e-mail: \{pawel.dobrzynski; bogdan.machowski\}@wat.edu.pl

** Institute of Precision Mechanics, Duchnicka 3 Str., 01-796 Warsaw, Poland; e-mail: stlipski@gmail.com

*** Polish Naval Academy, Faculty of Command and Naval Operations, Śmidowicza 69 Str., 81-127 Gdynia, Poland; e-mail: r.mietkiewicz@amw.gdynia.pl

**** ZAiUP AREX Sp. z o.o., Hutnicza 3 Str., 81-212 Gdynia, Poland; e-mail: tamberg@poczta.fm

\begin{abstract}
The article presents the analysis of the threats to ships of the Polish Navy resulting from the implementation systems of active neutralization for missiles of MANPADS (e.g. Grom, Igla, Mistral) to the armed forces of the Russian Federation.

The paper describes the most popular sea anti-aircraft missile sets based on MANPADS missiles and the capabilities of Russian multi-sensor systems for protection of Vitebsk class helicopters and aircraft (President-S). The article contains conclusions from the analysis of the capabilities of weapon systems and active disruption systems in the confrontation of a present ship with a modern combat helicopter and proposals for solving this problem by means of the diversification of missile of anti-aircraft systems.
\end{abstract}


$\underline{\text { Paweł Dobrzyński, Stanisław Lipski, Bogdan Machowski, Rafał Miętkiewicz, Sławomir Tamberg }}$

Key words:

marine combat systems, safety and security of navigation, multi-sensor MANPADS counteraction systems, armament and specialist equipment, rocket self-defence systems.

Research article

(C) 2018 Paweł Dobrzyński, Stanisław Lipski, Bogdan Machowski, Rafał Miętkiewicz, Sławomir Tamberg This is an open access article licensed under the Creative Commons Attribution-NonCommercial-NoDerivatives 4.0 license (http://creativecommons.org/licenses/by-nc-nd/4.0/) 


\section{INTRODUCTION}

The tasks of naval vessels of the Polish Navy are not limited only to operations carried out in the sea, but also near the coasts. According to the authors of this article, no intensive work are carried out in Poland, the results of which would allow to increase the possibility of defending Polish Navy vessels against attack by combat helicopters, for example through the innovative use of the latest technological and technological achievements. Taking into consideration data of active anti-MANPADS systems, the proposal to combat helicopters with the use of Grom-type antiaircraft sets can not be treated as a sufficient solution. Reports from military exercises taking place in Belarus and the Russian Federation show that portable anti-aircraft kits that can be used by self-guided missiles may prove ineffective in confronting with the latest systems of active disruption of the third generation [11]. Therefore, this publication is an attempt to interest subjects associated with maritime technology - the possibilities of increasing the safety of Navy ships (or civilian ships), which may be threatened by attacks of modern combat helicopters.

The dynamic nature of the modern battlefield is influenced by the ability to create threats from various places through a wide range of resources. A deeper analysis of the hazards of shallow water reservoirs and the possibility of transferring the burden of war operations to these regions requires that many threats are expected, among which helicopters (mainly shore-based coasting) can play a significant role. Short distances between the points of homing and action areas cause that the threat created by combat helicopters becomes real, especially in relation to surface vessels of small size - which constitute the majority in Polish Navy.

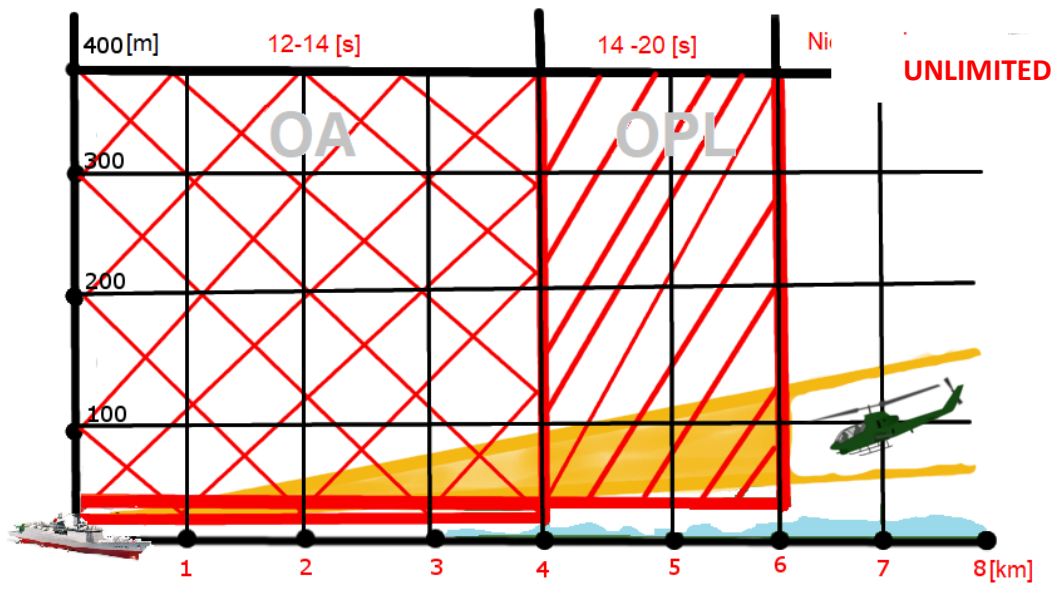

Fig. 1. Tactics of the combat helicopter: OA — artillery defence, OPL — defence against aviation [10] 
Fig. 1 shows that the operation of the helicopter outside the enemy's air defence zone significantly limits the range of possible targets, while the chances of ensuring machine safety increase strongly. This rule is used not only by pilots, but above all by constructors of modern on-board helicopter weapon systems. This is also the case, due to the limited signatures of small surface vessels, which undermine the sense of their combat by expensive anti-ship missiles. The list of helicopters of the Russian Federation (FR) carrying out tasks on the Baltic Sea is presented in tab. 1.

It is unacceptable that modern ships equipped with the most modern dedicated weapons (e.g. ORP 'Kormoran', ORP 'Ślązak'), built with the use of enormous resources, did not have an effective and effective defence system against threats from the upper hemisphere. Acquisition of anti-aircraft/anti-missile systems capable of counteracting airborne targets moving at high speed at low altitudes becomes a matter of priority when considering the necessary freedom of action of Polish naval forces.

Tab. 1. List of RF helicopters performing tasks over the Baltic Sea [based on 'Jane's Fighting Ships 2017-2018', ed. by Commodore Stephen Saunders RN, p. 701]

\begin{tabular}{|c|c|c|c|c|c|}
\hline Helicopter & $\begin{array}{l}\text { Kamov } \\
\text { Ka-52K } \\
\text { Katran }\end{array}$ & $\begin{array}{c}\text { Kamov } \\
\text { Ka-31 Helix }\end{array}$ & $\begin{array}{c}\text { Kamov } \\
\text { Ka-27PL } \\
\text { Helix A } \\
\text { Ka-29 Helix B } \\
\text { Ka-32 Helix D } \\
\end{array}$ & Mi-8 Hip & Mi-24 Hind \\
\hline $\begin{array}{c}\text { Operating } \\
\text { speed } \\
{[\mathrm{km} / \mathrm{h}]}\end{array}$ & 300 & 220 & 250 & $225-250$ & 335 \\
\hline $\begin{array}{c}\text { Range } \\
{[\mathrm{km}]}\end{array}$ & 459 & 300 & 800 & 900 & 1100 \\
\hline Armament & $\begin{array}{l}12 \times \text { ASMs } \\
\text { or } 23 \mathrm{~mm} \\
\text { cannons } \\
\text { or AAMs Igla } \\
\text { or } 80 \mathrm{~mm} \\
\text { air-to-ground } \\
\text { rockets } \\
\text { or ASMs Kh-35 } \\
\text { or Kh-38 }\end{array}$ & $\begin{array}{l}\text { Unarmed in } \\
\text { the reconnaissance } \\
\text { version }\end{array}$ & $\begin{array}{l}\text { - helicopter in } \\
\text { anti-submarine } \\
\text { version } \\
\text { - combat version } \\
\text { - - SAR version }\end{array}$ & $\begin{array}{l}\text { helicopter } \\
\text { equipped } \\
\text { with } 6 \\
\text { suspensions } \\
\text { (armament } \\
\text { versions) }\end{array}$ & $\begin{array}{l}\text { helicopter } \\
\text { in different } \\
\text { versions } \\
\text { of weapons }\end{array}$ \\
\hline
\end{tabular}

\section{OPPORTUNITIES FOR SHORT-RANGE ANTI-AIRCRAFT DEFENCE SYSTEMS SHIPS OF THE POLISH NAVY}

Modern marine forces mainly operate on coastal areas, which generates a specific set of threats. Due to the semi-closed nature of the Baltic Sea, with a meridional 
extent of $1.300 \mathrm{~km}$ and a parallel latitude of $600 \mathrm{~km}$, it should be assumed that the Navy units operating on that surface are permanently within the impact of the boundary aviation. When conducting activities in compressed and shallow water areas ${ }^{1}$, many interdependent factors have to be taken into account. The most important of them include ${ }^{2}$ :

- threat from shore rocket launchers and artillery batteries;

- the threat from modern anti-ship missiles of the water-water and air-water class (the ability to program points of return, bypassing islands, simultaneous attack from many directions);

- relatively easy detection from the shore and accurate tracking of the position of conducting operations;

- the intrinsic nature of many threats;

- intensification of the movement of units of various destinations (fishing, commercial and recreational units, ferries, passenger units, airplanes and helicopters for various purposes);

- threats from autonomous/unmanned systems (underwater and surface) used for reconnaissance (creation of a situation map for secretive attacks) and plans to attack selected targets (unmanned aerial systems UAV);

- occurrence of adverse hydrometeorological phenomena limiting the work of sensors;

- existence of artificial islands and elements of mining infrastructure (terminals, drilling platforms, wind farms), reducing the detection zone;

- the reach of mass media information, which facilitates the creation and development of emergency situations.

The specificity of contemporary challenges indicates a growing participation of naval forces in activities below the threshold of war. This does not mean, however, that the threats were reduced only to acts of terrorism. Therefore, in order for Navy RP to be able to carry out its tasks at the required level, it is necessary to ensure that the vessels have the maximum available resources to perform these tasks in the conditions of simultaneous counteraction of the opponent. Of particular importance here are the direct defence measures in the form of artillery and missile, or mixed anti-aircraft sets.

${ }^{1} \mathrm{CSW}$ - confined and shallow waters.

2 Prospective Operations in Confined and Shallow Waters, Study Paper, Centre of Excellence for Operations in Confined and Shallow Waters, Kiel 2015, p. 14.

$3(214) 2018$ 
$\underline{\text { Paweł Dobrzyński, Stanisław Lipski, Bogdan Machowski, Rafał Miętkiewicz, Sławomir Tamberg }}$

Tab. 2. Modern artillery equipment of Navy ships dedicated to fighting targets in the upper hemisphere

\begin{tabular}{|c|c|c|c|}
\hline Type & $\begin{array}{c}\text { Caliber } \\
{[\mathbf{m m}]}\end{array}$ & $\begin{array}{c}\text { Rate of fire } \\
\text { [shots/min] }\end{array}$ & $\begin{array}{c}\text { The effective range of fire } \\
\text { for airborne purposes [m] }\end{array}$ \\
\hline $\begin{array}{c}\text { OT0 Melara Mk-75 mod. } \\
\text { 0 }\end{array}$ & 76 & 120 & 20000 \\
\hline AK-176 & 76 & $1-120$ (control) & 15000 \\
\hline ZU-23-2M Wróbel I & 23 & $\begin{array}{c}1600-2000 \\
\text { practical 100) }\end{array}$ & 1500 \\
\hline ZU-23-2MR Wróbel II & 23 & $\begin{array}{c}1600-2000 \\
\text { (practical 400) }\end{array}$ & 4500 \\
\hline AK-630 & 30 & $4000-5000$ & 1500 \\
\hline Mk-15 Blok 0 Phalanx & 20 & 3000 (practical 989) & $?$ \\
\hline MARLIN WS & 30 & $?$ & 4000 \\
\hline KDA & 35 & 550 & 4500 \\
\hline
\end{tabular}

The armament of the ORP 'Ślązak' corvette in the discussed range: $76 \mathrm{~mm}$ OTO Melara gun and two OTO Melara cannons $30 \mathrm{~mm}$ MARLIN-WS. This system is complemented by 4 GROM rocket launchers. Corvette ORP 'Kaszub' was equipped in 2016 with the automatic 35mm KDA marine gun (Triton) with a fire control system installed on the ship, which uses an integrated ZGS-158 tracking head (sea version with a fire control station) [2]. The basic task of this system is to combat air targets, including flying drones and surface targets (effective resonance up to 5,000 m). For the purposes of defence of missile ships 660 (still built in the GDR, whose main armament is 8 missiles RBS-15 Mk III), the use of AK-176 cannon and $30 \mathrm{~mm}$ AK-630 artillery is expected.

The vast majority of Polish Navy vessels (minesweepers, mine destroyers, transport and mine ships, support vessels, auxiliary units) are armed with locally operated 23-mm artillery sets Wrobel I and Wróbel II. These sets have already been characterized many times in numerous studies. Nowadays, as their main purpose, one can indicate direct defence against asymmetric threats. These kits make it possible to combat airborne targets to a limited extent over short distances. Only shock units have a potential capable of combating air attack agents with the expected higher efficiency.

As a supplement to them, the use of Grom (Grom-M) missiles [6] is predicted, which are guided by gyro-stabilized heads with cooled infrared detectors - which is no surprise since these rockets have been used on many ships of many world naval vessels for many years. The use of missile sets with larger dimensions and hence larger ranges in the case of Polish ships seems to be very problematic due to their parameters. The basic advantages of using light anti-aircraft systems is their 
relatively low acquisition cost as compared to larger missiles of middle and middle range. Their range of effective impact (5-6 km horizontally and 3-4 km in the facade) abruptly reduces the effectiveness of the potential enemy's aircraft and helicopters [8].

\section{COMPARISON OF MARINE MISSILE SYSTEMS V-SHORAD}

The most common marine short-range missile systems are three types of missiles: the American Stinger, the French Mistral and the Russian Needle. Stinger-POST ${ }^{3}$ about symbol FIM-92B missiles are used in Stinger antiaircraft rocket systems. The head of this projectile reacts to two radiation bands - the infrared band and the ultraviolet band. Such a system makes it possible to target the projectile on a target with low thermal contrast and significantly reduces the susceptibility to interfering with the use of thermal traps.

Another modernization concerns the Stinger-RMP missile (Reprogrammable Micro-Processor) with the FIM-92C symbol introduced to arms in 1989. The guidance system of this projectile has been enriched with a reprogrammable microprocessor, which makes it possible to change the logic functions of assessing the nature of disturbances and the way they are filtered out. Further modifications (1995) of the Stinger rocket set were mainly related to software and power supply (lithium batteries) as well as to its adaptation to combat unmanned aerial vehicles (Stinger-RMP Block 1 /symbol FIM-92D).

In the simplest marine version of this set, in places providing the sector of fire and security of service, racks with rings are mounted to the deck of the ship, in which there is an operator with a portable Stinger anti-aircraft rocket set (fig. 2). The ring protects the operator from falling overboard, as well as ensuring the adoption of a proper and stable posture to perform fire tasks. On the ring are mounted handles that allow the operator to put down the set and fasten the IFF interrogator and spare power and cooling sources. The ring stand can be attached to the ship's deck permanently or removed if necessary.

The stand provides a 360-degree azimuthal sector of shooting, which can be divided into zones of responsibility, in the elevation angle the set allows performing fire tasks up to $+60^{\circ}$.

\footnotetext{
${ }^{3}$ Passive Optical Seeker Technique.
} 


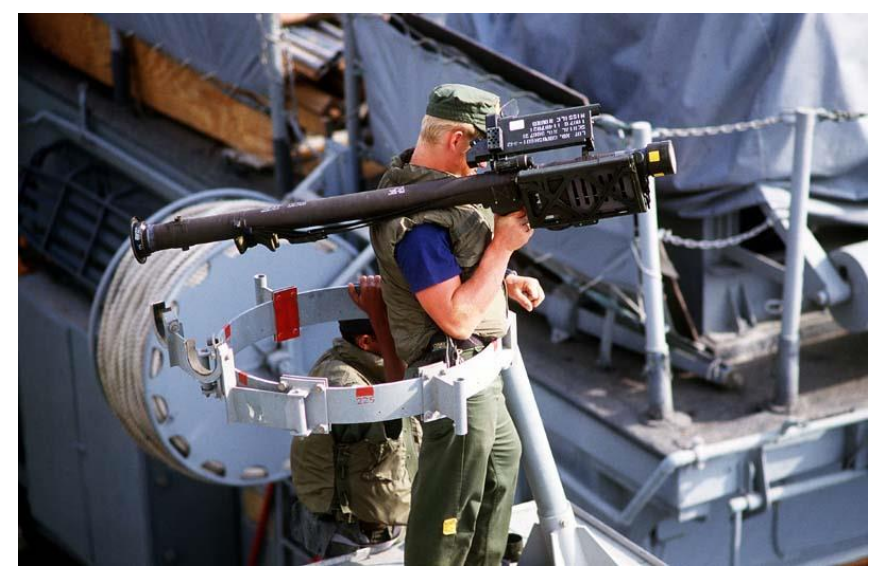

Fig. 2. The way of mounting the ring stand for the Stinger operator [20]

Another example of a launcher using Stinger missiles are the sets:

- manually controlled Stinger See Scorpion 1;

- remotely controlled Stinger See Scorpion 2.

Stinger See Scorpion 1 consists of two launchers placed on the base on two sides of the operator, an optical day-night viewfinder, an integrated starting mechanism, and an electric power supply and headphone system (fig. 4). The rotating base provides the operator with guidance of the launcher in the azimuth of $360^{\circ}$ and in the angle of elevation from $-20^{\circ}$ to $+60^{\circ}$. A $70 \mathrm{~mm}$ steel plate on board the ship is required to mount the launcher base. The power supply system provides power to all components during pre-start preparation and during the launch of the rocket. The kit together with rockets weighs $125 \mathrm{~kg}$. The operator receives information about the purpose of the ship's combat system through the headphones placed in the headphone. The system informs the operator when the Stinger rocket will extract the air object from the background and keeps track of the target while the operator decides when to use the set.

Stinger See Scorpion 2 consists of: a starter container, a stabilized launch pad base, a sensor system, a control console, and a system and power supply system control. The starter container contains four Stinger rockets and an integrated start mechanism and central cooling system for homing heads (fig. 3). The container was adopted from self-propelled land Avenger, Bradley Linebecker and LAV-AD antiaircraft systems. The power supply system provides power to all components during pre-start preparation and during rocket launch the power requirements for the set: $110 \mathrm{~V} \mathrm{AC}, 240 \mathrm{~V} \mathrm{AC}$ or $440 \mathrm{~V}$ AC (three-phase). The kit with rockets weighs approximately $450 \mathrm{~kg}$. 
In the case of the French Mistrals, due to the much larger mass of projectiles $(18.7 \mathrm{~kg})$, the marine versions of this anti-aircraft system are based on massive foundations. In October 1986, attempts were successfully made with the SADRAL, SIMBAD and later TETRAL launcher systems.

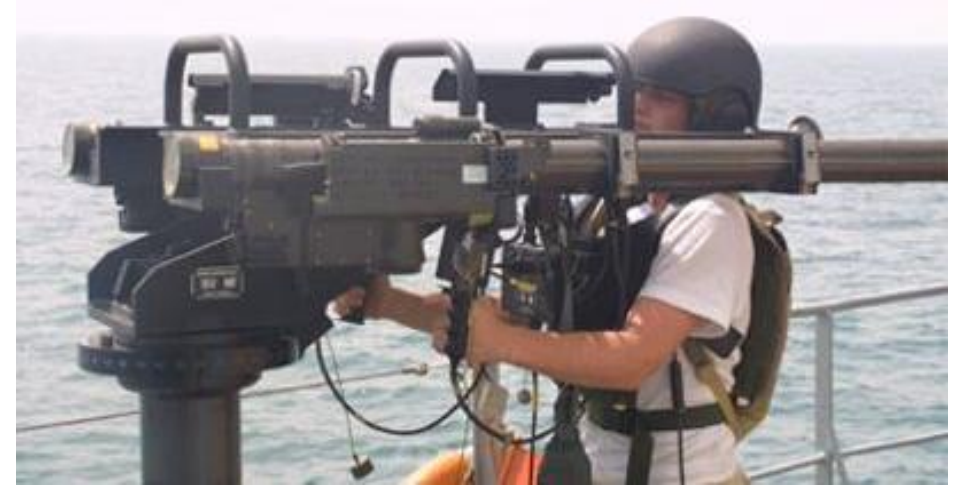

Fig. 3. Stinger See Scorpion 1 [16]

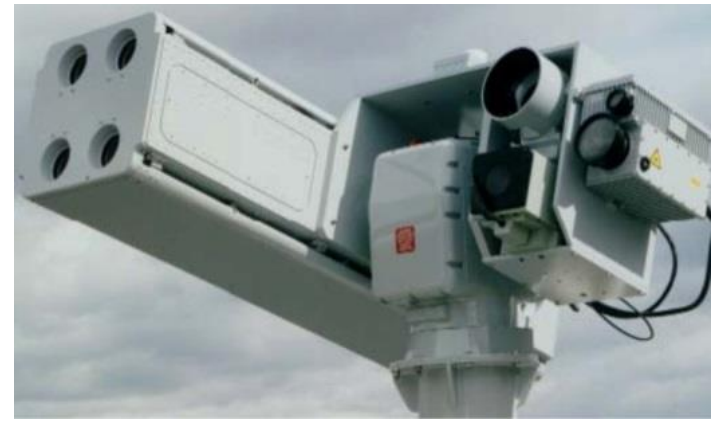

a)

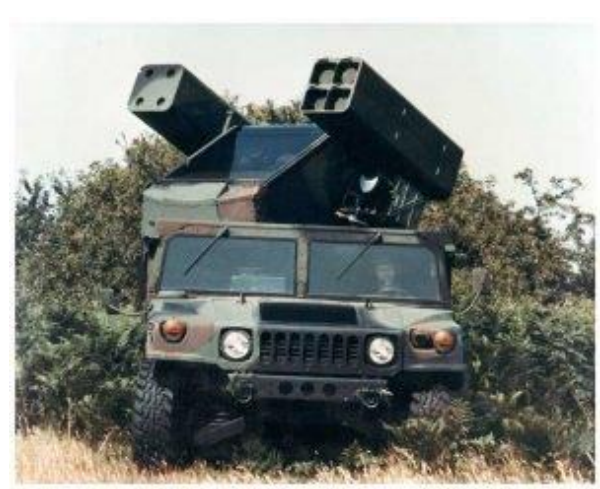

b)

Fig. 4. Anti-aircraft set: a) Stinger See Scorpion 2 and its original land application; b) Avenger anti-aircraft vehicle with Stinger rocket launchers on an unarmed humvee

In 1990, two successful fire tasks for the Sea Skimmer (TTL BTT-3 Banshee) were introduced, which were moving at $332 \mathrm{~km} / \mathrm{h}$. The first target was destroyed on the ground army range at a distance of $3 \mathrm{~km}$, when he was heading to the launcher, flying at a height of $6 \mathrm{~m}$. The second target was destroyed at a distance of $2.5 \mathrm{~km}$ by a missile fired from a ship launcher. The target was approaching the ship at a height of $10 \mathrm{~m}$. 
The Mistral missile guidance system has a viewing angle of $\pm 38^{\circ}$ and can be cooled in 2 seconds, i.e. when the gyro achieves its working speed. Behind the guidance system, gyroscope and servomechanism, there is a $2.95 \mathrm{~kg}$ explosion-shattering head with impact and laser detector. The head consists of $1 \mathrm{~kg}$ of explosive material and almost $2 \mathrm{~kg}$ of tungsten balls, increasing the possibility of injury. During the preparation for shooting, a replaceable battery-cooling system is also used, which provides for 45 seconds supply of a power supply bullet and cooling of the search and tracking head, which still needs to capture the target before launch.

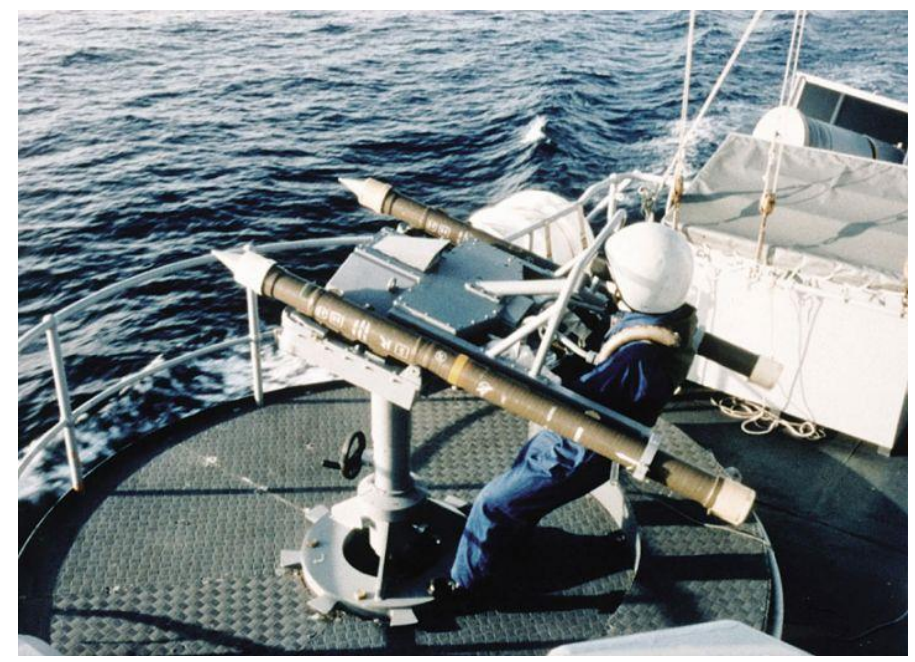

Fig. 5. SIMBAD 4

The SIMBAD rocket set has a height of $2.3 \mathrm{~m}$, needs free space within a radius of $1.5 \mathrm{~m}$ and can be installed on any $20 \mathrm{~mm}$ cannon base. It is equipped with an optical viewfinder with three magnifications and rotates in the facade within the angles from $-5^{\circ}$ to $+55^{\circ}$.

The light anti-aircraft missile system TETRAL has four containers-launchers. The weight of the launcher on the deck is $600 \mathrm{~kg}$, the entire set with 4 rockets in $650 \mathrm{~kg}$ containers. This set is controlled from the console (CMS - multi-function console) through the servo block. The launcher is stabilized, has a height of $1.5 \mathrm{~m}$ on the deck and requires free space in a radius of $2.5 \mathrm{~m}$.

The next pre-start functions are controlled by a digital sequence system located on the launcher. The missile also receives electric power from the launcher

${ }^{4}$ Systeme Integre de Mistral Bitube d'Auto-Defence. 
and argon to cool the head (from two spare cylinders). After detecting the object, the launcher is rotated at the right angle in the horizontal plane, and when changing the angle of the elevation, the projectile is started according to a similar time sequence as in the SIMBAD set. The start of the first rocket can take place after 5 seconds, from the moment of detecting the air object - start the next rocket after 3 seconds.

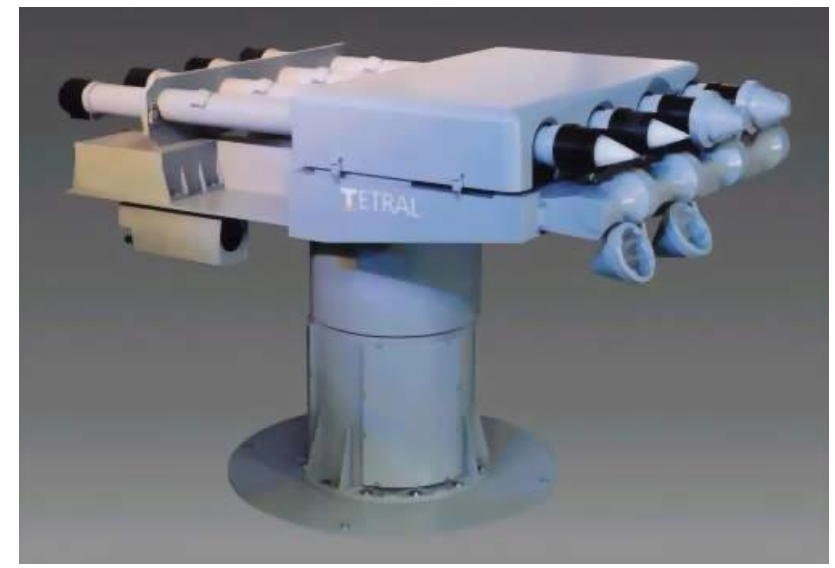

Fig. 6. TETRAL [15]

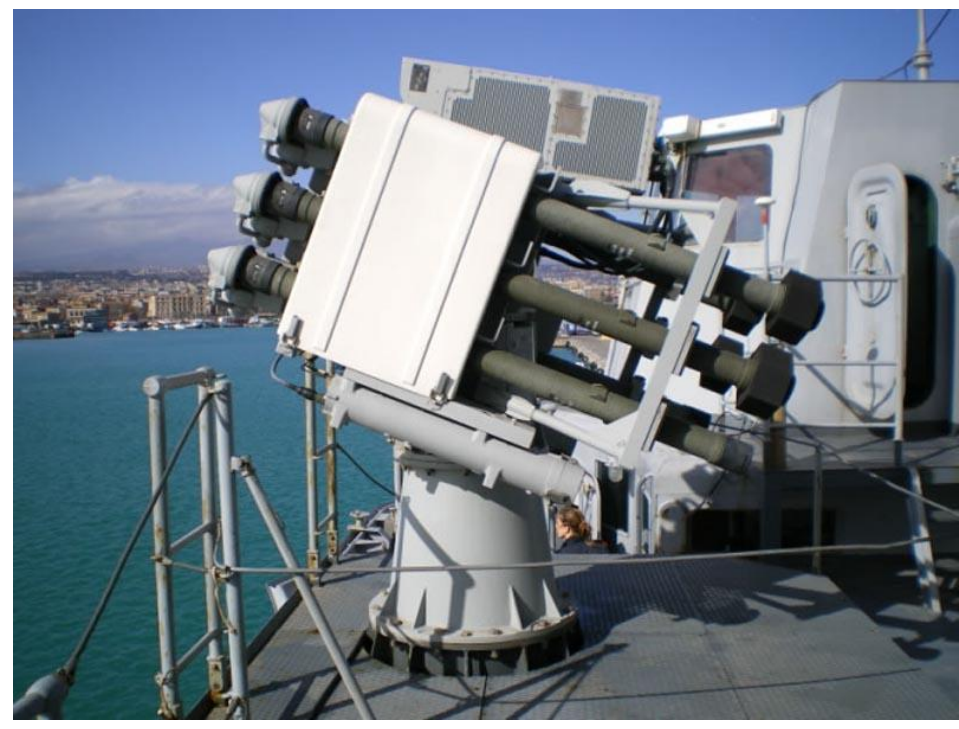

Fig. 7. SADRAL ${ }^{5}[17]$

${ }^{5}$ Systeme d'Auto-Defence Raprochee Anti-aerienne Leger. 
The SADRAL ship missile system has 6 launcher containers and a TV camera that is replaced by a thermal imaging camera at night and in bad weather. The weight of the mounting kit on the deck is $1080 \mathrm{~kg}$. This set is controlled from the console under the base (weighing $280 \mathrm{~kg}$ ) through a servo block, weighing $410 \mathrm{~kg}$. The deck kit has a height of $2.1 \mathrm{~m}$ and requires free space in a radius of $2.6 \mathrm{~m}$.

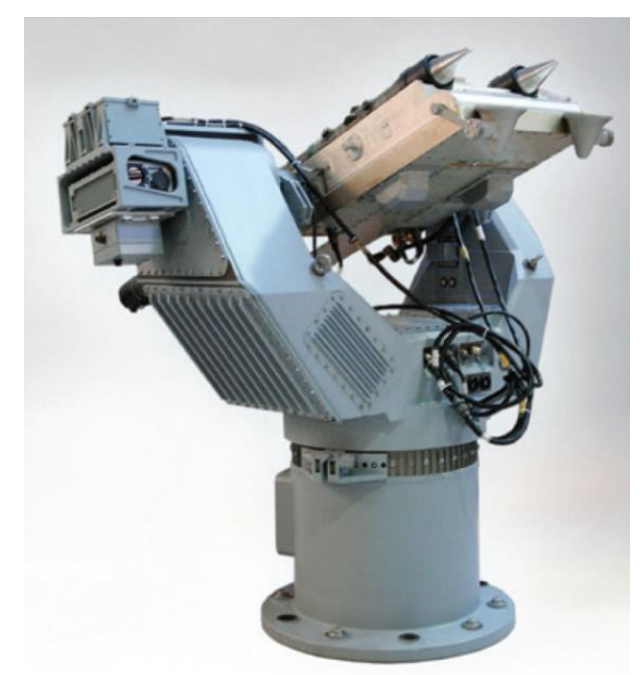

Fig. 8. SIMBAD-RC (Remotely Controlled) [MBDA]

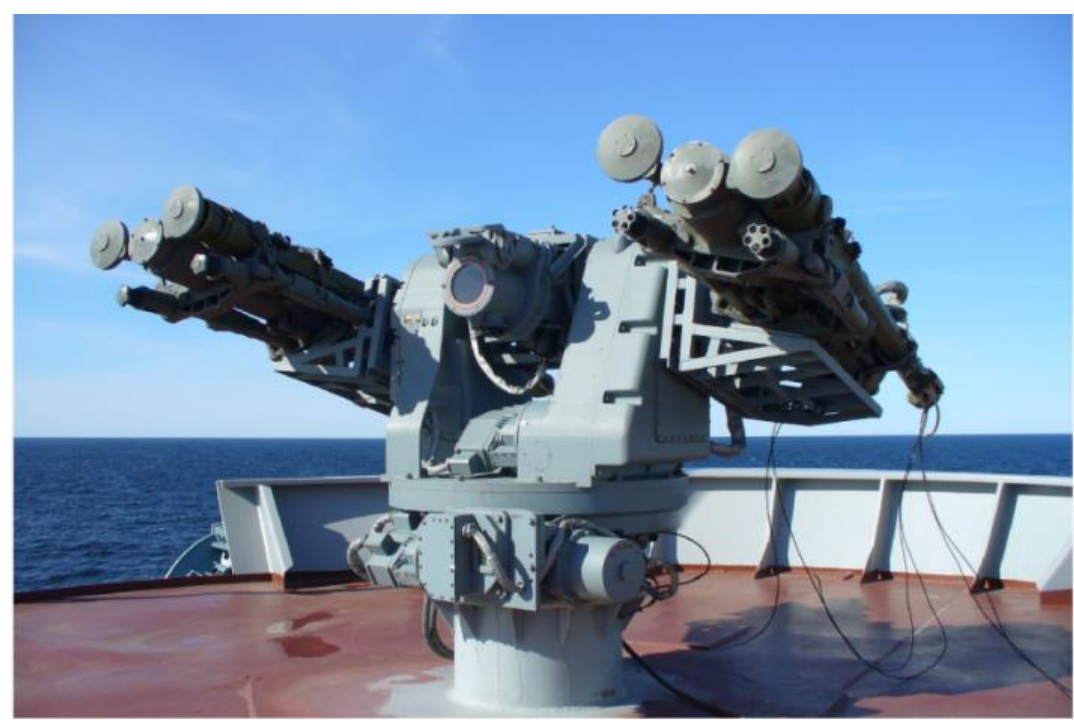

Fig. 9 GIBKA-R [23] 
One of the latest marine sets based on Mistral missiles is the MBDA SIMBAD-RC kit weighing $450 \mathrm{~kg}$. It allows remote control of the launcher, with two missiles which has all elements of the fire control system and visual field stabilization on board.

Also in the Russian Federation, marine systems of stabilized missile launchers are being developed and offered. An example of this is the GIBKA-R set (fig. 9).

This set supports 4 to 8 missile launchers (9M39/9M342). System response time is $6.6 \mathrm{~s}$ from detection and target indication. The high efficiency of the $9 \mathrm{M} 342$ missile against air targets is attributed to the increase in the weight of the explosive in its warhead and the new proximity fuse, allowing the target to hit both in the case of a direct hit, and at a distance of $1.5 \mathrm{~m}$ from the target. Gibka-R is remotely controlled and can be directed towards targets detected by on-board radar systems. The final missile guidance is achieved in the control module via the television observation system. According to the specifications of the constructors, the visual detection range of the aircraft by the control module is from 12 to $15 \mathrm{~km}$.

Tab. 3. Comparison of selected missile anti-aircraft systems

with newly developed systems self-defence system and masking ships using missiles

\begin{tabular}{|c|c|c|c|c|c|c|c|c|}
\hline Name & 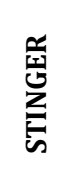 & 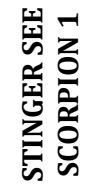 & 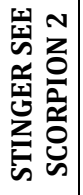 & 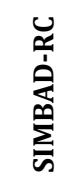 & 窇 & 胥 & 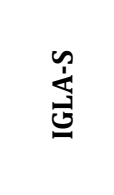 & $\begin{array}{l}\sum_{0} \\
\text { 은 }\end{array}$ \\
\hline Type of missile & \multicolumn{3}{|c|}{$\begin{array}{c}70 \mathrm{~mm} \\
\text { FIM-92 Stinger }\end{array}$} & \multicolumn{3}{|c|}{$\begin{array}{l}90 \mathrm{~mm} \\
\text { Mistral }\end{array}$} & $\begin{array}{l}72 \mathrm{~mm} \\
\text { Igla-S }\end{array}$ & $\begin{array}{c}72 \mathrm{~mm} \\
\text { Grom }\end{array}$ \\
\hline $\begin{array}{l}\text { Max. number } \\
\text { of missiles }\end{array}$ & 1 & 2 & 4 & 2 & 6 & 4 & 1 & 1 \\
\hline Missile length [m] & \multicolumn{3}{|c|}{1.52} & \multicolumn{3}{|c|}{1.86} & 1.64 & 1.69 \\
\hline Diameter $[\mathrm{mm}]$ & \multicolumn{3}{|c|}{70} & \multicolumn{3}{|c|}{90} & 72 & 72 \\
\hline Rocket weight [kg] & \multicolumn{3}{|c|}{10.1} & \multicolumn{3}{|c|}{19.7} & 11.7 & 10.5 \\
\hline Weight of the laucher [kg] & 5.1 & 105 & 450 & 480 & 600 & 1080 & 7.15 & 6 \\
\hline $\mathrm{V}_{\text {MAX }}$ rockets $[\mathrm{m} / \mathrm{s}]$ & \multicolumn{3}{|c|}{725} & \multicolumn{3}{|c|}{800} & 800 & 800 \\
\hline$D_{\text {MAX }}[\mathrm{km}]$ & \multicolumn{3}{|c|}{4.8} & \multicolumn{3}{|c|}{6.0} & 6.0 & 5.0 \\
\hline $\mathrm{H}_{\text {MAX }}[\mathrm{km}]$ & \multicolumn{3}{|c|}{3.8} & \multicolumn{3}{|c|}{3.0} & 3.5 & 3.5 \\
\hline Weight of warehead [kg] & \multicolumn{3}{|c|}{$3.0(?)$} & \multicolumn{3}{|c|}{2.95} & 2.5 & 1.35 \\
\hline
\end{tabular}

The analysis of the above examples shows that ships and their crews around the world are equipped with more and more advanced rocket systems of direct shielding and leading companies develop them in close cooperation with national Navy - in order to get the most out of them. Unfortunately, only study works are 
carried out in Poland in this area, and many financial resources of the Polish taxpayer, was drowned in utopian projects, an example of which may be the work of adapting Grom missile sets since 20 years to the possibility of using them from an airplane or helicopter 6 .

In the tab. 3 compared earlier marine short-range rocket sets with the capabilities of PZR Grom produced in Poland. An important parameter of PZR Grom, which deviates from similar American, French or Russian systems, is almost three times lower mass of warhead explosives, which in comparison with the armour of the newest combat helicopters may be a condition insufficient to destroy or damage them. A much more serious difficulty in the effectiveness of all of the above-mentioned kits is the introduction on the decks of Russian helicopters of an active disruption of their homing heads.

\section{OPPORTUNITIES FOR DEFENCE AND ATTACK OF MODERN COMBAT HELICOPTERS RUSSIAN FEDERATION}

In 2016, the Defence23 portal reported that the Russian Company Russian Helicopters (created after the transformation of Kamov and Moscow Mill Plants) ${ }^{7}$ he started equipping the Mi-52 helicopters he produced with an advanced protective system President-S ${ }^{8}$ designed to neutralize air-to-air missiles. This system was developed and produced by Przedsiębiorstwo Techniki Radioelektronicznej (KRET). The President-S system protects aircrafts from radar-directed anti-aircraft fire and anti-aircraft missile attacks, including MANPADS infrared-guided ones such as Russian 9K32 Strieła-2, Igla-1 or Chinese Hong Ying-5 (HN-5).

Depending on the configuration of the system and the helicopter on which the system is installed with the most-often-named name Vitebsk or President-S. Based on data obtained from OSINT $^{9}$ It can be assumed that work on this system was started already in 2004 and the system was first installed onboard the Kamow Ka-50 helicopter in August 2004. Its development and integration as well as tests

6 'Attempts to adapt the Grom missiles for the W-3Sokół/Głuszec helicopter were carried out already in 2000. as part of the Gad-G program'. See [online], https://www.defence24.pl/ pdf/?article=polskie-uzbrojenie-dla-smiglowcow [access 17.04.2018].

7 Now: Государственная корпорация по содействию разработке, производству и экспорту высокотехнологичной промышленной продукции 'Ростех'. See [online], https://rostec.ru/ [access 17.04.2018].

8 In Russian: Президент-C.

${ }^{9}$ Open-source intelligence. 
and evaluations ended in 2009. Defence24 then informed that President-S was to be mounted on Mi-28NE and Ka-52 assault helicopters, as well as equipped with rotorcraft used by leading personalities from the Russian authorities. In 2010, articles appeared on Russian portals informing that the next stage of system development will be the defence against the volley of many anti-aircraft missiles ${ }^{10}$. President-S was shown at the MAKS-2011, Farnborough-2012, Paris Airshow 2013, Hellirussia 2014 and 2018. The system was designed in accordance with the requirements of open architecture, which allows it to function as integrated with the on-board complex. The design of the system can be adapted to be placed on any type of aircraft, both in the version with a single transmission head and one laser, and in a variant with several heads and lasers.

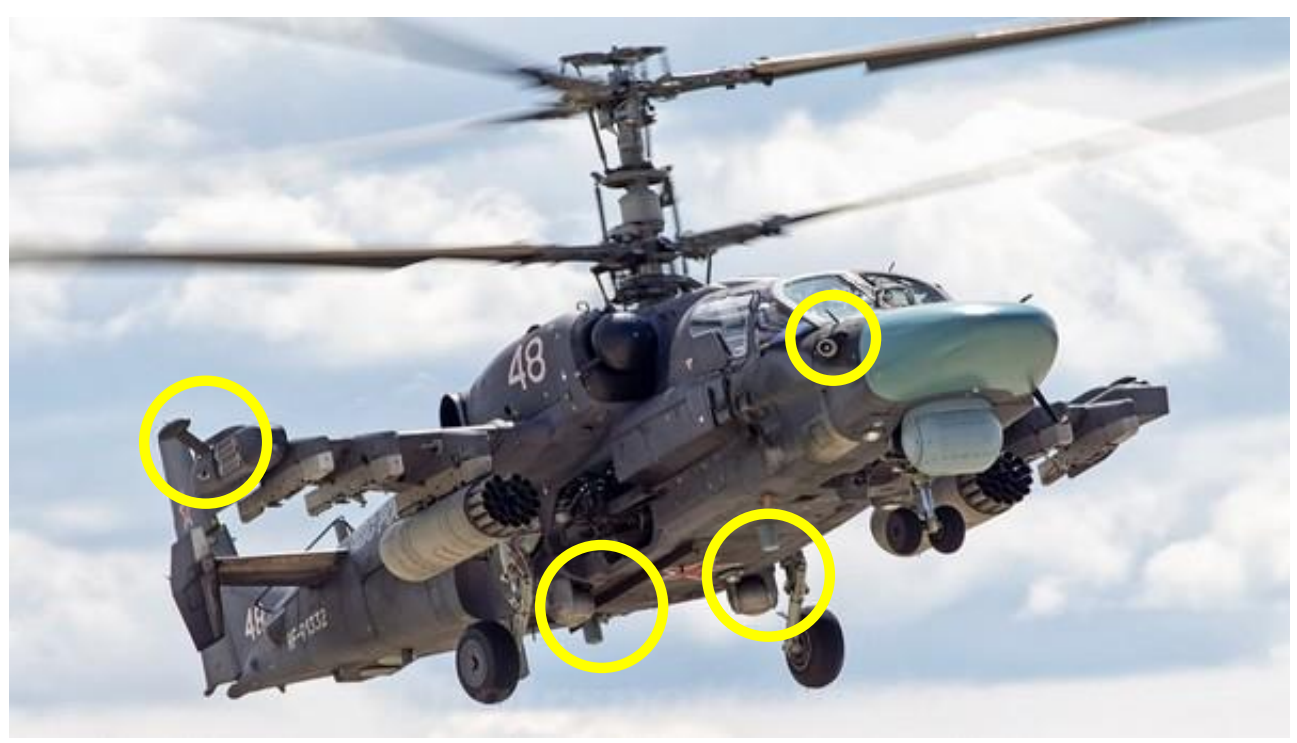

Fig. 10. Kamov Ka-52 helicopter with the Vitebsk-52 system [14]

The Russian Federation Army tested various configurations of the President-S system, among others during a combat mission in Syria (helicopters Mi-8, Mi-17, Ka-52). Most probably, in Syria for the first time in combat conditions, the Russian air force was used by Kamow Ka-52 helicopter (Hokum-B). An anonymous source TASS reported that the helicopter was equipped with the L370-5 Vitebsk interference system, allowing effective protection against MANPADS. The 'alligator' was to attack groups of fighters in the Homs province, using two types of Ataka 9M120 rockets.

10 Машинавойнь Система оптико-электронного подавления ЗРК, [online], http://warcyb.org.ru/ news/sistema_optiko_ehlektronnogo_podavlenija_zrk/2010-06-24-50 [access 17.04.2018].

3 (214) 2018 
On Monday, August 1, 2017 in the early morning hours, in the area of the village of Araqib southeast of Aleppo, the Russian Mi-8AMTSz helicopter was shot down by Syrian fighters in the Idlib province. The machine took part in combat operations in the Aleppo area. Analysis of the photos of the broken Mi-8AMTSz indicates that the helicopter was equipped with the L370-5 system, in particular the element of the L370-5 system mounted on the helicopter's tail beam is visible. As a result of the helicopter's shooting down, this element has not been destroyed. It is not known who came into possession of the elements of the L370-5 system. The most important fact that arises from the activity of Russian helicopters in Syria is that it has not been found since then, when the Russian helicopter equipped with the President's L370-5 system was shot down. This may also indicate that modifications could be made to the L370-5 system to improve its performance.

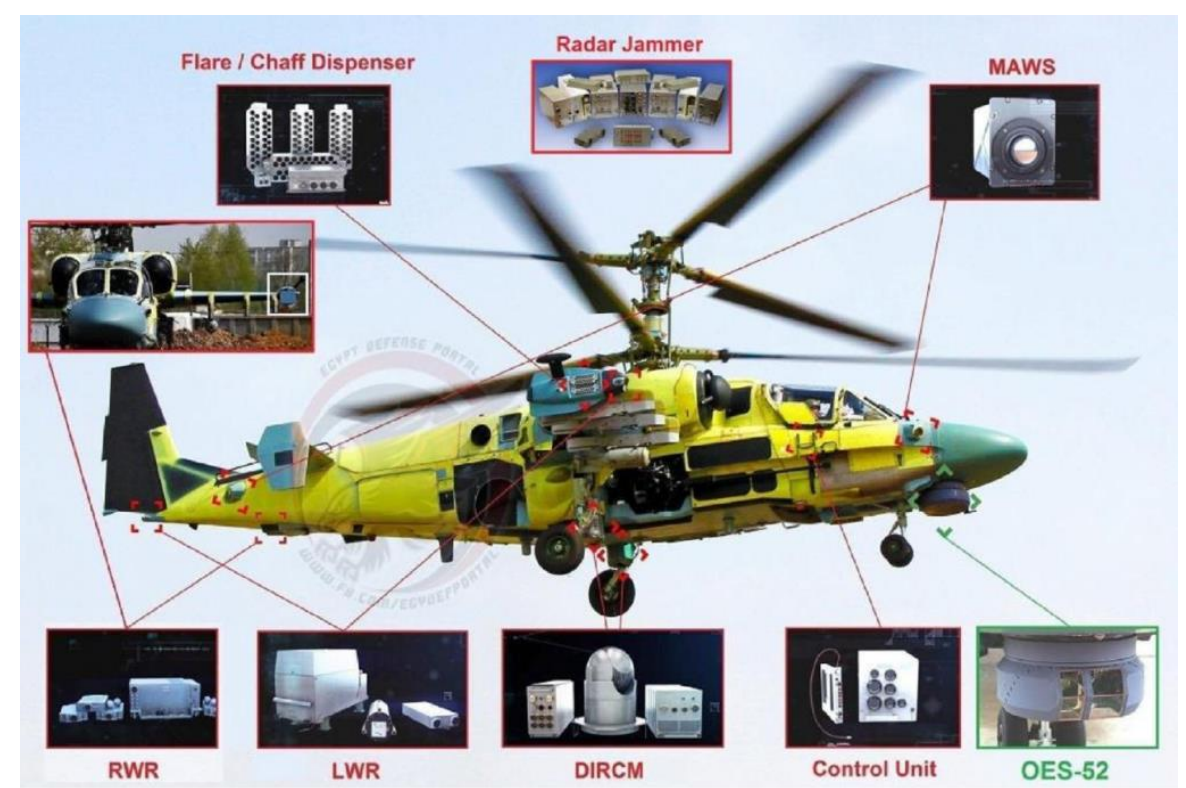

Fig. 11. Ka-52 with Vitebsk-52 [14]

The President-S system includes a laser irradiation detector, sensors warning against incoming missiles, electro-optical laser computer-controlled interference subsystem (which is one of the key effectors detecting MANPADS) and launchers of apparent targets. The sensors and system effectors can be mounted both in the structural elements of the helicopter and on the external fixing points. The kit has a modular construction and can be completed with fire protection systems for radar-directed anti-aircraft systems. 


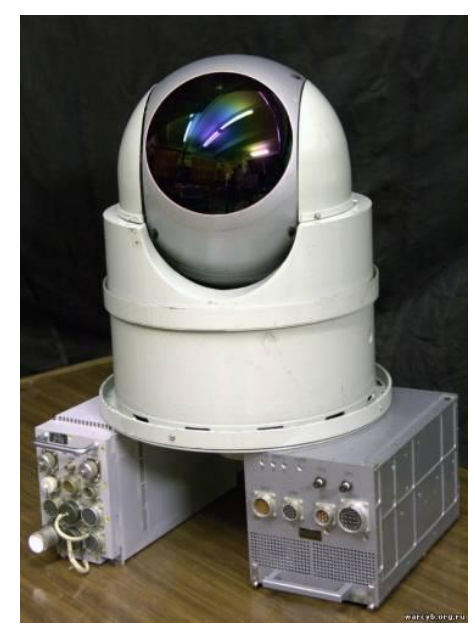

Fig. 12. Optoelectronic jamming station L370-5 [13]

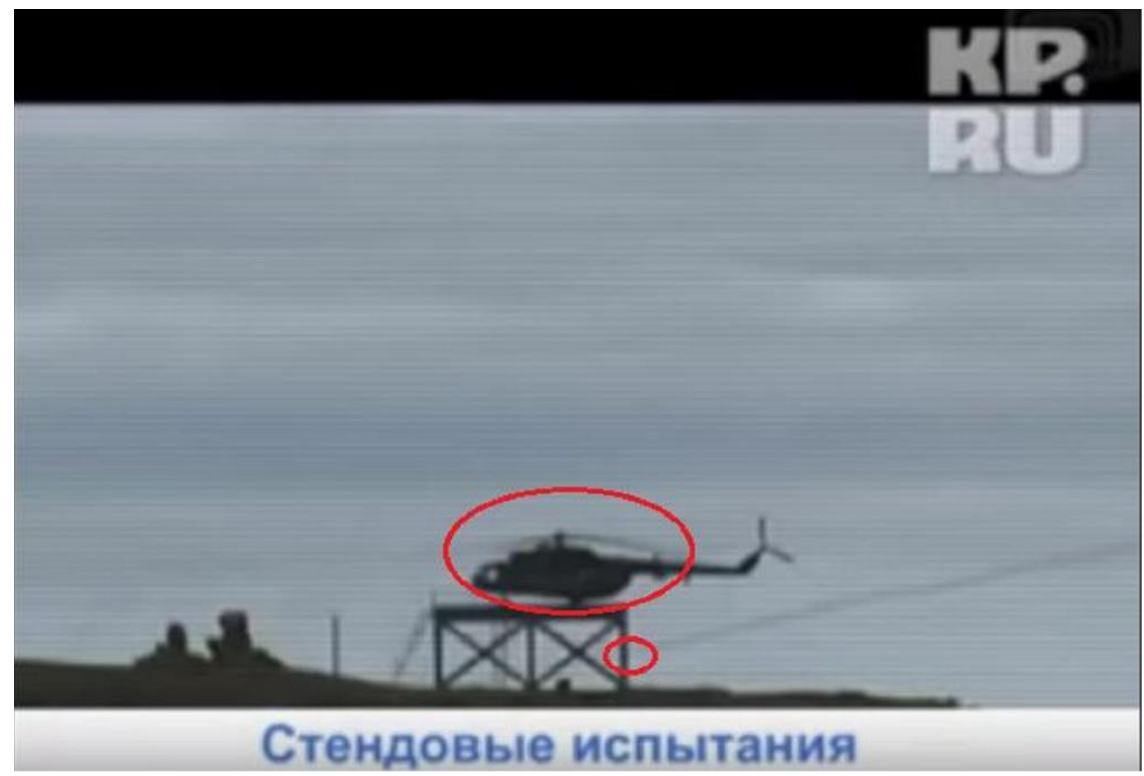

Fig. 13. A fragment of the film illustrating the shooting of a physical helicopter with the system L370-5 [3]

The Russians tested the system by firing Igla- 1 missiles towards the Mi- 8 helicopter placed on a special raised platform. During the tests, several missiles were fired from a distance of 1000 meters without hits. From the materials presented by Russian Helicopters available in OSINT sources, it appears that during the trials the system proved to be highly effective. The protected helicopter was fired from 
handheld anti-aircraft guns, and none of the missiles could hit the attacked machine. You can get to the information that the effectiveness of the President-S system is the result of the use and integration of several warning subsystems (directional laser irradiation sensors and sensors locating incoming missiles in the space around the helicopter), connected with automatically computer-controlled flare dispensers and electronic disruption subsystem, including electronic interception heads using technologies DIRCM 11 — equivalent AN/AAQ-24(V) Northrop Grumman.

The export version of the jammer known as L370E-8 was first presented during the Eurosatory exhibition in 2010 by the Russian export agency Rosoboronexport. The recipients of Mi-17S and Ka-52 helicopters equipped with the President-S system became Egypt and probably ultimately may be Algeria and other countries in Asia or Africa. The Egyptian edition of the system received an advanced version using a semiconductor laser that operates at a $360^{\circ}$ angle horizontally and $90^{\circ}$ vertically. It is used in conjunction with the sensors for warning against next-generation UV bullets. The L370E-8 jammer version was promoted at the exhibition as one of the main elements of the integrated DAS (simplified version of Vitebsk), proposed for a wide range of assault and transport helicopters.

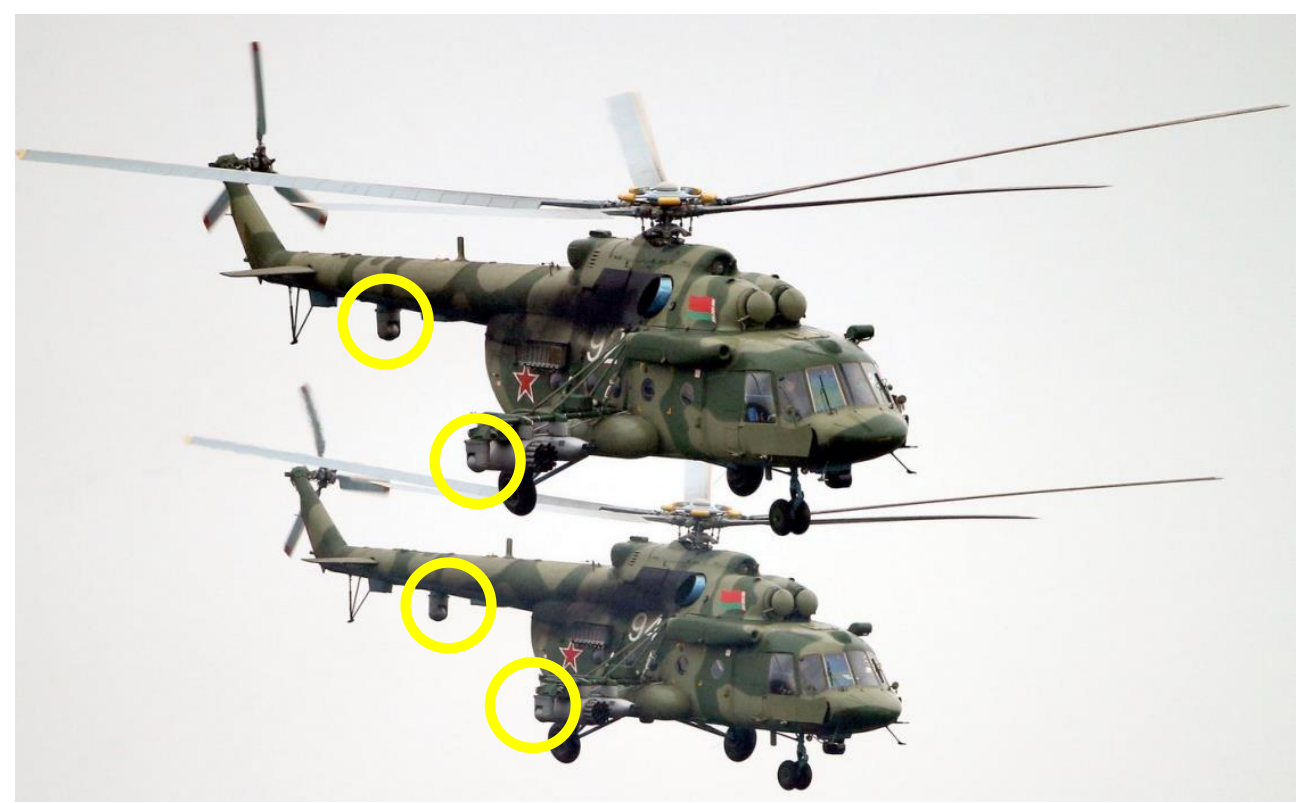

Fig. 14. Russian Mi-17 helicopters with the L370-5 system during exercises ZAPAD-2017 [21]

11 Directional Infrared Countermeasure. 
Many photos taken during the ZAPAD 2017 exercises ongoing in Belarus indicate that the installation of the L370-5 system is common and is no exception on the platforms of such helicopters as Mi-8, Mi-17 or Ka-52. In the case of Mi-17 helicopters, in some cases there were no L370E-8 devices on a girder on one side of the helicopter (instead of three there are two L370E-8 devices installed) - it is not known whether this results from savings or other technical reasons.

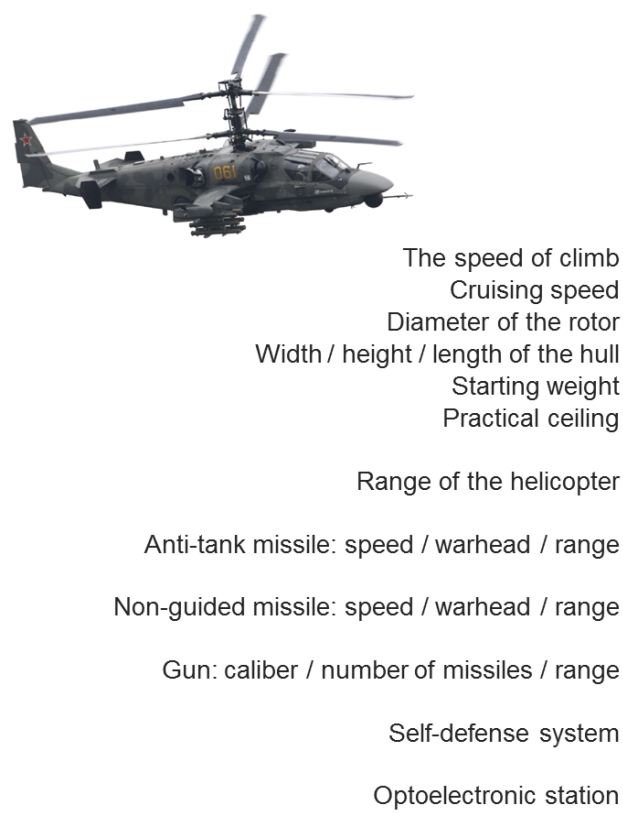

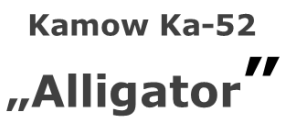

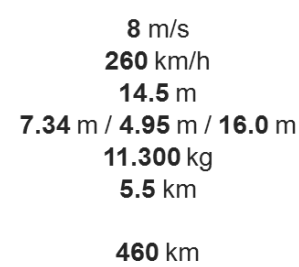

WIRCH 9K121: $610 \mathrm{~m} / \mathrm{s} / 12 \mathrm{~kg}$ HEAT / $12 \mathrm{~km}$

S-8: 610 m/s / $3.6 \mathrm{~kg} \mathrm{HEAT} \mathrm{/} 4 \mathrm{~km}$

SZIPUNOW 2A42: $30 \mathrm{~mm} / 240$ b. / $1.8 \mathrm{~km}$

PLATAN | VITEBSK | L370-5 “President-S”

KOLS (TV IR / Laser Range Finder / Laser llum.)

Fig. 15. Basic tactical and technical parameters of the Kamow Ka-52 Alligator helicopter

The analysis of the capabilities of the latest FR battle helicopters based on the analysis of publicly available materials shows that they may have an advantage over most Polish Navy vessels - which results from the following conditions:

1. Ka-52 helicopters have a minimized thermal signature and can move at high horizontal speeds just above the surface of the sea, so they can introduce into the fight element of surprise resulting from late detection by on-board thermal and radar systems of ships.

2. The element of surprise can be enhanced by modern helicopter missile systems, which can be exemplified by a laser-guided missile WIRCH 9K121, with a range of $12 \mathrm{~km}$ and a $12 \mathrm{~kg}$ warhead. A helicopter equipped with these missiles can therefore attack ships far from the range of typical anti-aircraft defence systems - without exposing themselves to the fire response of the ship. 
3. Ka-52 helicopters can hover in the air using field shields such as islands, civilian ships, dunes or trees for the most effective attack on the MW ship.

4. Ka-52 helicopters can take off from ships or civilian ships in the depths of the sea basin, increasing their range to the extent enabling them to operate throughout the Baltic Sea area.

5. Ka-52 helicopters can be used for precise droop of naval mines or jamming stations of communication and navigation systems, which in the moment selected by the crew may impair the effectiveness of the ship's defence.

6. Ka-52 helicopters can attack ships with classic or cassette bombs, with a ceiling that prevents their defences by means of typical artillery systems such as $23-\mathrm{mm}$ ZU-23MR, 35-mm KDA or Grom rockets (fig. 16).

7. Ka-52 helicopters are equipped with active systems for disrupting Grom-class missiles. The mere possession of President-S L-370-5 increases the morale of the helicopter crew - while increasing situational awareness, operational confidence and a tendency to bear greater risk. The analysis of the capabilities of the latest FR battle helicopters based on the analysis of publicly available materials shows that they may have an advantage over most Polish Navy vessels - which results from the conditions described in the next paragraphs.

8. Ka-52 helicopters have a minimized thermal signature and can move at high horizontal speeds just above the surface of the sea, so they can introduce into the fight element of surprise resulting from late detection by on-board thermal and radar systems of ships.

9. The element of surprise can be enhanced by modern helicopter missile systems, which can be exemplified by a laser-guided missile WIRCH 9K121, with a range of $12 \mathrm{~km}$ and a $12 \mathrm{~kg}$ warhead. A helicopter equipped with these missiles can therefore attack ships far from the range of typical anti-aircraft defence systems - without exposing themselves to the fire response of the ship.

10. Ka-52 helicopters can hover in the air using field shields such as islands, civilian ships, dunes or trees for the most effective attack on the MW ship.

11. Ka-52 helicopters can take off from ships or civilian ships in the depths of the sea basin, increasing their range to the extent enabling them to operate throughout the Baltic Sea area.

12. Ka-52 helicopters can be used for precise dumping of naval mines or interference stations of communication and navigation systems, which in the moment selected by the crew may impair the effectiveness of the ship's defence.

13. Ka-52 helicopters can attack ships with classic or cassette bombs, with a ceiling that prevents defences by means of typical artillery systems such as 23-mm ZU-23MR, 35-mm KDA or Grom rockets (fig. 16). 
14. Ka-52 helicopters are equipped with active systems for jamming Grom-class missiles. The mere possession of President-S L-370-5 increases the morale of the helicopter crew - while increasing situational awareness, operational confidence and a tendency to bear greater risk.

\section{A PROPOSAL OF A 70 MM ROCKET SYSTEM THAT ELIMINATES THE OPPONENT'S ADVANTAGE}

In 2012 at the Faculty of Mechatronics and Aviation of the Military University of Technology, at the Institute of Mechatronic Systems (formerly Institute of Rocket Technology), the problem of the urgent need to modernize possessed, among others, by Polish Navy of V-SHORAD self-defence missile systems. A team was formed among the scientific staff of the institute, which set itself the goal of finding a solution to the problem by implementing new types of homing heads and infrastructures with increased ranges and power of the warhead - at the expense of their manoeuvrability. One of the ideas was to develop a head that will use the L-370-5 system laser to navigate the helicopter equipped with it.

Unfortunately, the innovative ideas of the team members were perceived as a threat to the lobby associated with the production of existing missile systems in Poland. The Institute of Mechatronic Systems was closed under the pretext of the lack of one full-time researcher in the full-time staff, under another pretext the team member was forced to leave the Military University of Technology and the others to address other problems of military technology. The topic was returned only on the occasion of the establishment of Polska Grupa Zbrojeniowa S.A. and changes in the attitude of the main producer of optoelectronics for the Polish Army - the Warsaw PCO S.A.

According to the authors of this article, the response to the threats resulting from the introduction of better armored and equipped combat helicopters on the armaments is urgent to implement a universal missile missile in Poland to eliminate the superiority of helicopters over V-SHORAD systems.

The purpose of such a project would be the practical implementation of a prototype of a family of missiles compatible with NATO calibre $(2.75$ " $70 \mathrm{~mm})$ and various types of warheads. The system would allow, in addition to achieving compatibility with NATO army launchers, to combat ground targets, air or surface enemy, up to $10 \mathrm{~km}$. 


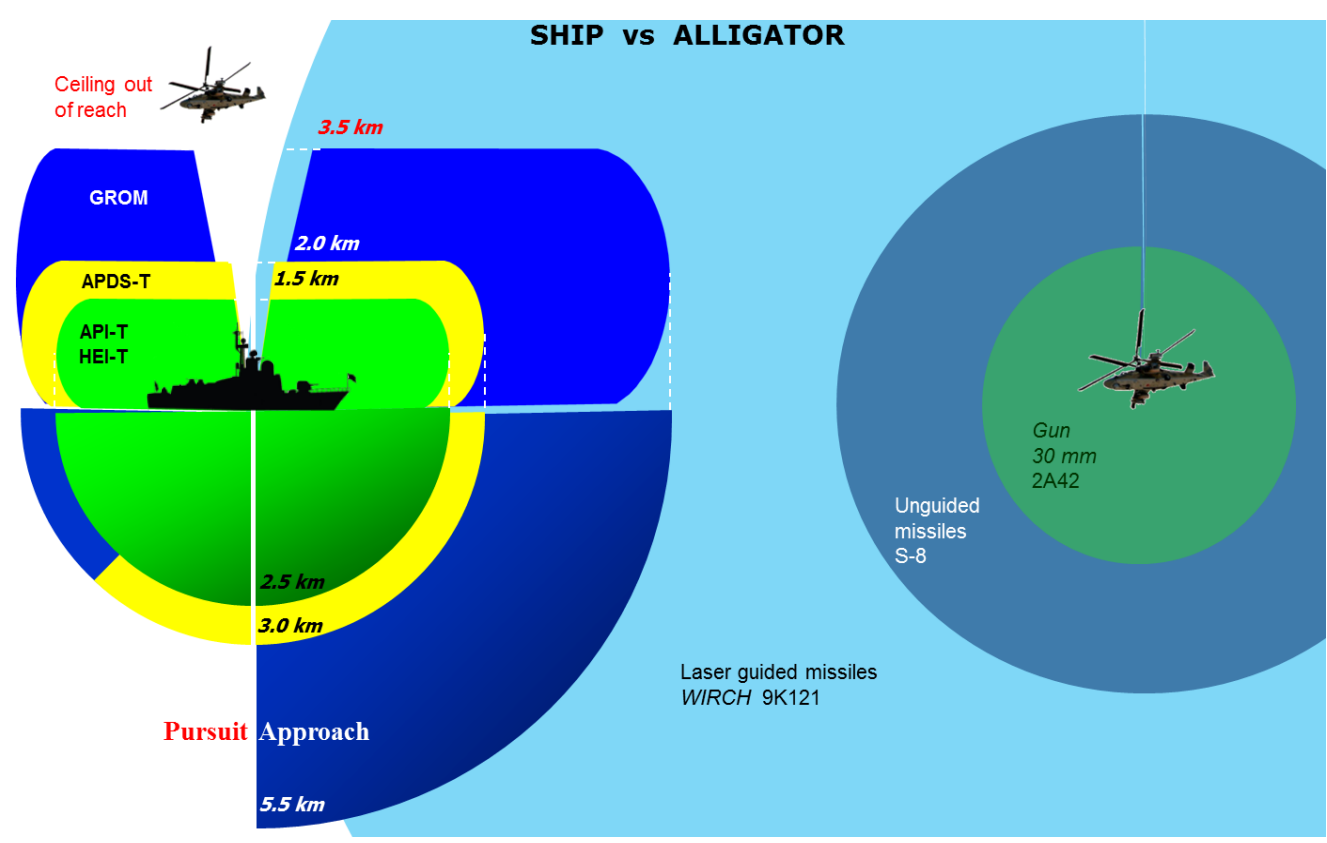

Fig. 16. Comparison of the ranges of typical anti-aircraft weapons of Polish Navy vessels with on-board weapons of the Aligator Ka-52 combat helicopter

The simplicity of the proposed solution results from the features characterizing the system proposed by specialists from the Military University of Technology, which is missing from the MANPADS sets owned by Navy:

1. No need to have a boot mechanism to launch the rocket, which simplifies the system's operation, its reliability and also speeds up the speed of operator training.

2. Possibility of autonomous work on automated MLRS, whose relatively small dimensions make it possible to mount them on every Polish Navy ship.

3. Lack of on-board gas-cooled detectors - all required signals for the autopilot are obtained from the mosaic detector and the appropriate application software.

4. Lack of spinning of the projectile - thanks to which it is possible to use analog controls and novel missile control algorithms developed in WAT.

5. Possibility of firing 'straight ahead' or shooting at 'intercept in flight'.

6. Possibility to use marching engine sets purchased in NATO countries (e.g. adapted from the Hydra-70 system, compatibility of weapon systems).

7. Increasing the effectiveness of the warhead by increasing the amount of explosives by eliminating the gyroscopic optical tracking head (typical for MANPADS missiles e.g. Grom). 
8. Simplification of logistics and transport safety - modular construction of missiles enables separate transport of each of its elements (e.g. marching engine, fuse, warhead, etc.) in dedicated collective packaging.

All $70 \mathrm{~mm}$ components necessary for the implementation of the missile weapon system are available nationally and can be manufactured or adapted by companies belonging to Polska Grupa Zbrojeniowa S.A. and integrated by Polish research and development centers such as OBR Centrum Techniki Morska S.A. or PCO S.A.

\section{COMPARISON OF PARAMETERS OF SELECTED ROCKETS}

Caliber

Weight of the rocket

Overloads available

Control system

Cooling type

The maximum angle of view of the head

The real angle of view of the detector

The ability to capture the target on the fly

Maximum speed of targets

Time to shoot

The average speed of the flight

Guiding method

Maximum working time of the head )

The method of launching a projectile

Type of rudders

Maximum range

Estimated annual demand of the MND

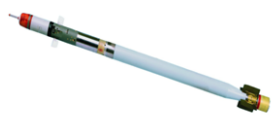

Anti-aircraft missile system "GROM"

$72.2 \mathrm{~mm}$ (USSR)

$10.6 \mathrm{~kg}$

$18 \mathrm{~g}$

1-channel

cooled with nitrogen (35 Mpa)

120 ' (peleng)

15

lack of possibility

$400 \mathrm{~m} / \mathrm{s}$

$5 \mathrm{~s}$

$570 \mathrm{~m} / \mathrm{s}$

prop. navigation 30 s

external start engine

metastatic $+/-15^{\circ}$

$5.5 \mathrm{~km}$

$200 \mathrm{cop}$.

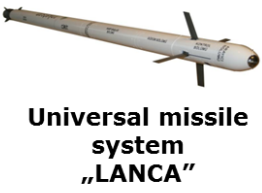

$70 \mathrm{~mm}\left(2.75^{\prime \prime}\right.$ NATO $)$

$9.8 \mathrm{~kg}$

$30 \mathrm{~g}$

2-channel

uncooled

$600^{\prime}$ (constant)

600 '

full opportunity

$500 \mathrm{~m} / \mathrm{s}$

$<1 \mathrm{~s}$

$800 \mathrm{~m} / \mathrm{s}$

prop. navigation no limits marching engine analog $+/-10^{\circ}$ $10.0 \mathrm{~km}$ $2000 \mathrm{cop}$

Fig. 17. Comparison of characteristics of the missile Grom and developed by the author team 2.75 projectile Lanca

Based on the data of the Hydra system rocket with the MK 66 MOD 6 engine, a series of simulation tests were carried out, examples of which are shown in fig. 18 and 19. The simulation results confirm the assumed tactical and technical design requirements for the $70 \mathrm{~mm}$ (2.75 ") missile system. Noteworthy is the small mass of the projectile with the warhead, which is less than $10 \mathrm{~kg}$ and the increased maximum range.

The strong argument for the urgent need to implement missile systems proposed by the team is that their operation is cheap and practically maintenance-free (use would only require emergency training of seamen loading missiles on the launcher).

$3(214) 2018$ 


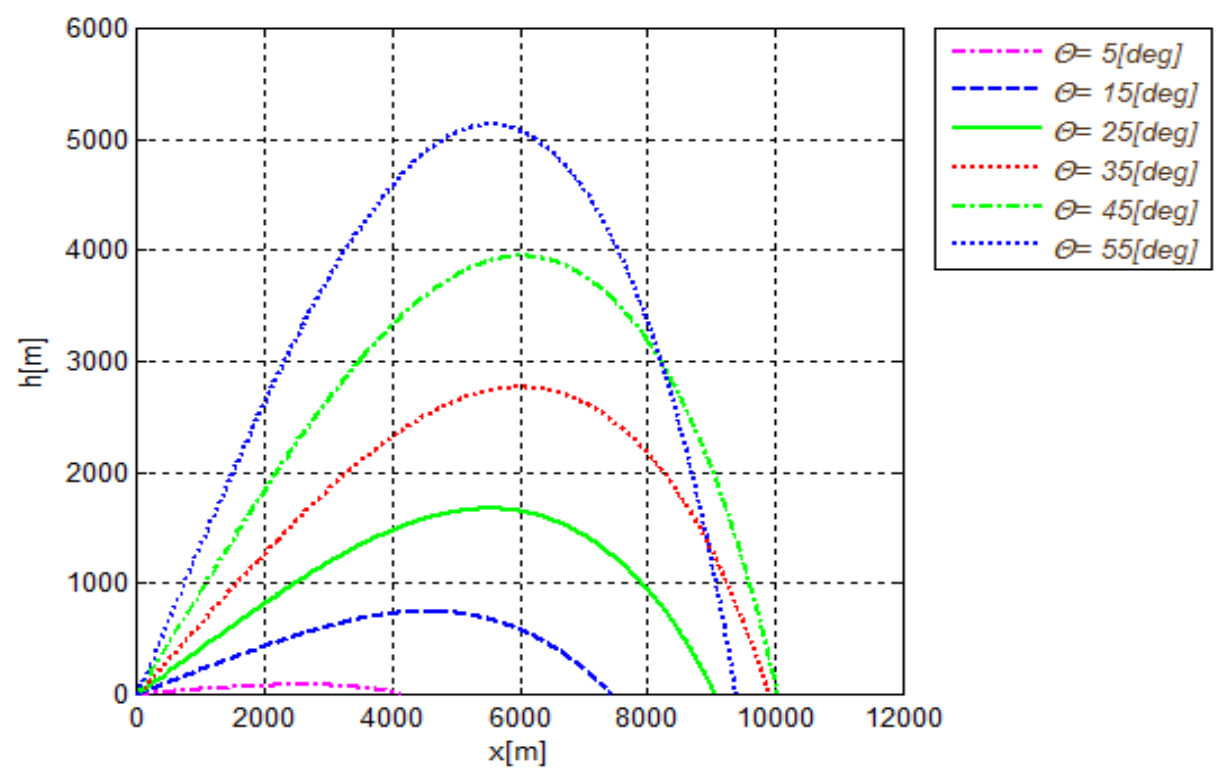

Fig. 18. Rocket flight path $70 \mathrm{~mm}(2.75$ ") for a parametrically variable starting angle (computer simulation)

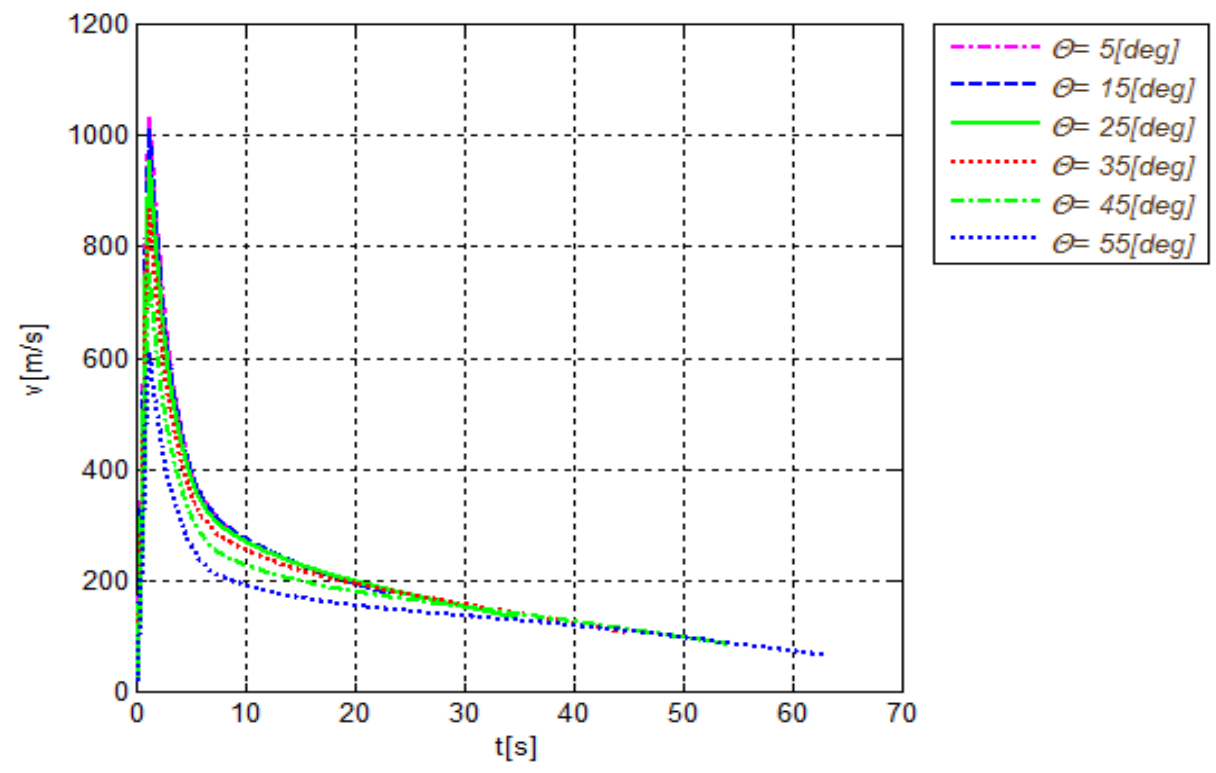

Fig. 19. Changing the flight speed of the rocket $70 \mathrm{~mm} \mathrm{(2,75")}$ as a function of time for a parametrically variable starting angle (computer simulation) 
In order to better illustrate the possibilities of such a system, the author team proposed a comparison of different types of missiles with the use of a graph including two indicators:

1) $E_{T}$ transport efficiency determined as:

$$
E_{T}=\frac{m_{W}}{m_{M}},
$$

where:

$m_{W}[\mathrm{~kg}]$ - mass of a warhead;

$m_{M}[\mathrm{~kg}]$ - mass of a missile.

2) $E_{\mathrm{PZ}}$ speed and range efficiency defined by the formula:

$$
E_{P Z}=V_{M} \cdot R_{M}
$$

where:

$V_{M}[\mathrm{~m} / \mathrm{s}]$ - maximum speed of a missile;

$R_{M}[\mathrm{~m}]$ - range of a missile.

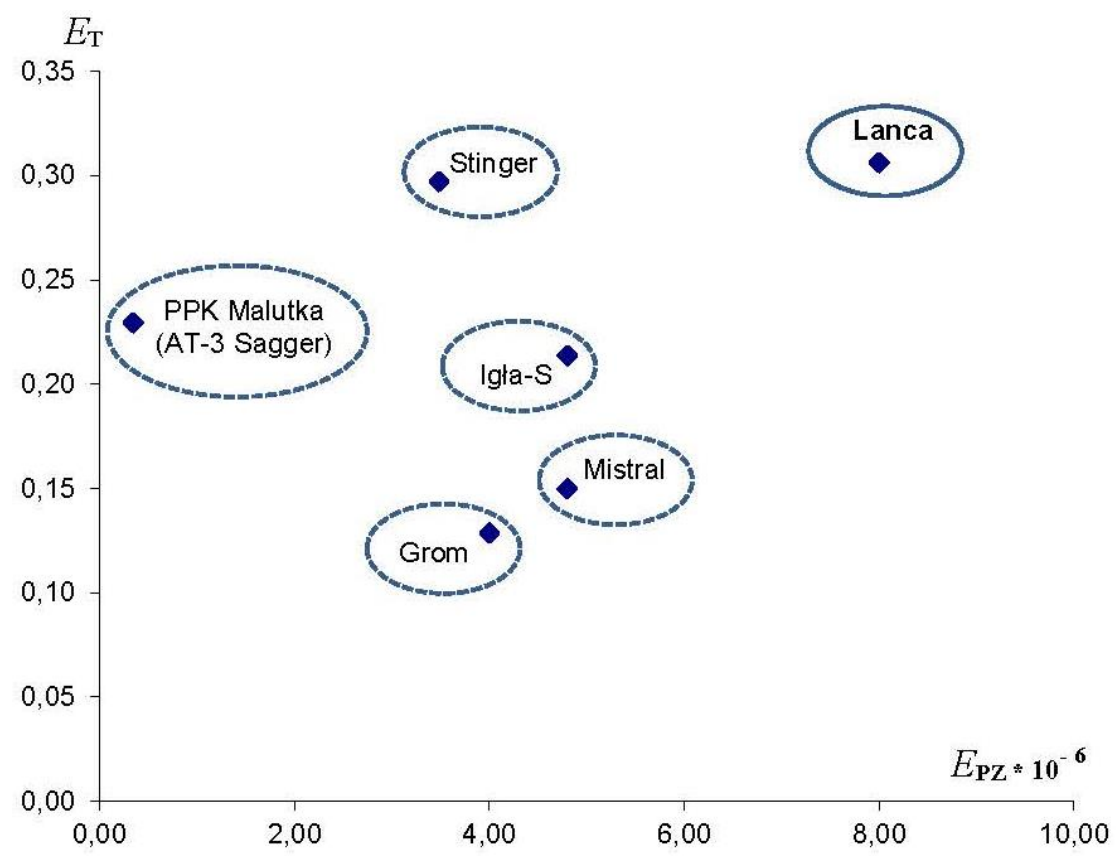

Fig. 20. Comparison of tactical and technical parameters of selected rocket systems in the space of transport efficiency $\left(E_{T}\right)$ and speed-range $\left(E_{P Z}\right)$ 


\section{CONCLUSIONS}

1. The use of combat helicopters against MW vessels is subject to specific restrictions related to the risk of their shooting down. Polish Navy has limited capabilities to combat helicopters resulting from the late detection of objects flying at low altitudes. The time deficit resulting from the late detection prevents manual use of existing warfare agents.

2. Improving the possibility of fighting combat helicopters by naval vessels of the Polish Navy requires new and more effective multi-layer anti-aircraft defence systems, including automatic - network-centric (autonomous in the event of system disturbances) - multi-lead - rocket launchers.

3. The use of MANPADS sets with classic optoelectronic target detectors is effective only in the case of helicopters without the new generation of active self-defence systems commonly used by the FR.

4. The helicopter designers, taking into account the properties of MANPADS warheads, design modern helicopters so that they become insensitive to these heads, therefore the warheads of MANPADS systems owned by MW RP are not able to seriously damage an armored combat helicopter - the disadvantage of these warheads is irrational axial dissipation of the shock wave impulse and unsatisfactory fragmentation of their side effect, which is forced by the thin-walled body of the missile.

5. Many countries buy ready-made missiles for incidental operations, but if sovereignty and independence are involved, developing their own systems is a warrant, and international cooperation is not an obstacle to the production of products fully controlled by Poland.

6. It should be emphasized that Poland as a manufacturer of MANPADS systems caught up with the solutions of the world's leading producers around 2000. Currently, global manufacturers offer systems classified to the fourth generation Polish solutions achieve a significantly lower level. Any attempts to change this state are probably blocked by the lobby taking profits from the monopolistic position of the MANPADS manufacturer in Poland. In the authors' opinion, delays may be due to the fact that the forces controlling the production were more concerned with the migration of the most profitable (or least labor-intensive) parts of the production work to private companies than on the further development of these systems. 


\section{REFERENCES}

[1] Dobrzyński P., Lipski S., Machowski B., Olszewski T., Koncepcja polonizacji pocisków rakietowych kalibru 2,75 ", XXI Międzynarodowa Szkoła Komputerowego Wspomagania Projektowania, Wytwarzania i Eksploatacji [XXI International School of Computer Aided Design, Generation and Operation], Jurata 2017, pp. 119-133, [Polonization concept for 2.75 caliber missiles - available in Polish].

[2] Dura M., System automatycznej armaty morskiej AM-35 — nie tylko dla Marynarki Wojennej?, [online], http://www.defence24.pl/system-automatycznej-armaty-morskiej-am-35-nie-tylkodla-marynarki-wojennej [access 03.02.2018], [The AM-35 automatic cannon system — not only for the Polish Navy? — available in Polish].

[3] L370-5 (President-S) Live Fire Tests, [online], https://www.youtube.com/watch?v=hHem1vrVl6o [access 17.04.2018].

[4] MANPADS and small arms control, 'The Ploughshares Monitor', Vol. 25, No. 3, Autumn 2004, [online], http://www.lexingtoninstitute.org/wp-content/uploads/manpads-scale-nature-threat.pdf [access 19.04.2018].

[5] Mitigating the MANPADS threat: international agency, U.S. and Russian efforts, March 2005, [online], https://calhoun.nps.edu/bitstream/handle/10945/2321/05Mar_Bartak.pdf?sequence=1 [access 19.04.2018].

[6] Piorun MANPADS Missile Programme Delayed. Deliveries Expected Soon, [online], http://www.defence24.com/piorun-manpads-missile-programme-delayed-deliveries-expectedsoon [access 19.04.2018].

[7] Prospective Operations in Confined and Shallow Waters, Study Paper, Centre of Excellence for Operations in Confined and Shallow Waters, Kiel 2015.

[8] Zieliński Z., Szulc T., Grom i Piorun nie dla MON?, 'Raport, Wojsko, Technika, Obronność, No. 03/15, p. 5 [Grom and Piorun not for the Ministry of National Defense? - available in Polish].

[9] Машина войны. Система оптико-электронного подавления ЗРК, [online], http://warcyb.org.ru/ news/sistema_optiko_ehlektronnogo_podavlenija_zrk/2010-06-24-50 [access 17.04.2018], [The Machine of War. The system of optical-electronic suppression system - available in Russian].

[10] Проект Аrта3 Realwar. Тактика применения вертолета, [online], http://arma3realwar.ru/ [access 19.04.2018], [Project Arma3 Realwar. Helicopter tactics — available in Russian].

[11] http://eng.ktrv.ru/production_eng/323/529/ [access 19.04.2018].

[12] http://nevskii-bastion.ru/simbad/ [access 17.04.2018].

[13] http://warcyb.org.ru/news/sistema_optiko_ehlektronnogo_podavlenija_zrk/2010-06-24-50 [access 17.04.2018].

[14] http://www.khanpaklive.com/wp-content/uploads/2017/07/08-101.jpg [access 17.04.2018].

[15] http://www.maquetland.com/v2/images_articles/mistraltetral.jpg [access 17.04.2018].

[16] http://www.navalhistory.dk/English/History/1989_2003/TheNavyAfter1989.htm [access 17.04.2018].

[17] http://www.okretywojenne.mil.pl/uzbrojenie/mistral/sadral_04.jpg [access 17.04.2018].

[18] https://breakingdefence.com/2017/04/boeing-upgrades-air-defence-vs-russians-avenger-shorad/ [access 17.04.2018]. 
[19] https://rostec.ru/ [access 17.04.2018].

[20] https://twitter.com/d__mitch/status/778582800454807552 [access 17.04.2018].

[21] https://wiadomosci.wp.pl/manewry-zapad-2017-przeszly-do-aktywnej-fazy-na-poligonzaproszono-zagranicznych-obserwatorow-6167247725676673a [access 17.04.2018].

[22] https://www.defence24.pl/pdf/?article=polskie-uzbrojenie-dla-smiglowcow [access 17.04.2018].

[23] https://www.kbm.ru/en/production/pzrk/pupzrk/365.html [access 17.04.2018].

\section{MOŻLIWOŚCI ZWALCZANIA ŚMIGŁOWCÓW BOJOWYCH \\ PRZEZ OKRECTY MARYNARKI WOJENNEJ RP W ŚWIETLE ROZWOJU SYSTEMÓW AKTYWNEGO PRZECIWDZIAŁANIA ZESTAWOM PRZECIWLOTNICZYM TYPU MANPADS}

\section{STRESZCZENIE}

W artykule przedstawiono najpopularniejsze okrętowe zestawy przeciwlotnicze na bazie pocisków typu MANPADS w konfrontacji z możliwościami rosyjskich wielosensorowych systemów ochrony śmigłowców i samolotów klasy Vitebsk (President-S). Dokonano analizy zagrożeń okrętów MW RP wynikających z wdrożenia do sił zbrojnych Federacji Rosyjskiej systemów aktywnego neutralizowania samonaprowadzających się na podczerwień pocisków klasy ziemia - powietrze bliskiego zasięgu (Stinger, Grom, Igła, Mistral).

W artykule zawarto wnioski z analizy możliwości stosowania systemów broni i systemów zakłóceń aktywnych w starciu współczesnego okrętu z nowoczesnym śmigłowcem bojowym oraz propozycje rozwiązania tego problemu za pomocą dywersyfikacji rakietowych systemów OPL.

Słowa kluczowe:

morskie systemy walki, bezpieczeństwo i ochrona żeglugi, wielosensorowe systemy przeciwdziałania MANPADS, uzbrojenie i sprzęt specjalistyczny, rakietowe systemy samoobrony okrętów.

Article history

Received: 22.05 .2018

Reviewed: 12.07 .2018

Revised: $\quad 25.09 .2018$

Accepted: 26.09 .2018 